superior mesenteric angiography in acute ischaemia remains controversial. Appreciable mesenteric embolus or stenosis of the superior mesenteric artery may occasionally be recognised, but attention should be drawn to accumulating evidence that catheterisation or manipulation of a diseased aorta may itself predispose to cholesterol emboli. ${ }^{3+}$ These commonly affect kidneys, pancreas, and peripheral circulation but may also affect the gastrointestinal tract.

In addition to the release of oxygen derived free radicals by the gut mucosa, there is evidence that trapping and activating white cells in the microcirculation contributes to the cycle of stasis and endothelial and mucosal damage that occurs in intestinal ischaemia." When reperfusion is considered, prostacyclin analogues, which vasodilate, reduce white cell and platelet aggregability, and confer a "cytoprotective" effect on ischaemic tissues,' should be added to the list of potentially useful protective pharmacological adjuncts. We are currently evaluating the role of such compounds in preventing reperfusion injury.

F C T SMITH C P SHEARMAN

Queen Elizabeth Hospital,

Birmingham B15 2TH

1 Marston A. Acute intestinal ischaemia. BMF 1990;301:1174-6. (24 November.

2 Smith FCT, Boon A, Shearman CP, Downing R. Spontaneous cholesterol embolisation: a rare cause of bowel infarction. Eurf Vasc Surg (in press).

3 Gaines PA, Cumberland DC, Kennedy A, Welsh CL, Moorhead P, Rutley MS. Cholesterol embolisation: a lethal complication of vascular catheterisation. Lancet 1988;i: 168-70.

Tomson CRV. Cholesterol embolisation after angiography. Lancet 1988;i:643.

5 Dahlberg PJ, Frecentese DF, Cogbill TH. Cholesterol embolism: experience with 22 histologically proven cases. Surgery 1989 105:737-46.

6 Ernst E, Hammerschmidt DE, Bagge V, Matra A, Dormand $J A$. Leucocytes and the risk of ischaemic diseases. $f_{A M A}$ 1987;257:2318-24.

7 Vane JR. Prostacyclin in the cardiovascular system in health and disease. In: Schrör K, ed. Prostaglandins and other eicosanoids in the cardiovascular system: proceedings of the 2nd international symposium. Basel: Karger, 1985:7-28.

\section{Renal artery stenosis}

SIR,-Dr A H Choudhri and colleagues gave a timely reminder of the high incidence of unsuspected atheromatous renal artery stenoses in patients with peripheral vascular disease. ${ }^{\prime}$ Bonomo et al found appreciable $(>50 \%)$ stenoses in 29 of 249 normotensive patients with peripheral vascular disease, ${ }^{2}$ and we found 72 unilateral and 22 bilateral appreciable stenoses in 213 patients with peripheral vascular disease.

The increasing use of angiotensin converting enzyme inhibitors to treat all grades of hypertension makes these results particularly important. We have seen four cases of renal failure caused or aggravated by angiotensin converting enzyme inhibitors in the past three months. All four patients had obvious non-renal vascular disease, and three required dialysis.

The development of renal failure severe enough to need dialysis in older patients with widespread vascular disease is not a simple reversible condition. Despite this the latest issue of the British National Formulary still lists renovascular hypertension as an indication for using antiotensin converting enzyme inhibitors." Although the possibility of renal impairment is mentioned, the warnings are in our view inadequate, suggesting that stopping treatment will allow renal recovery. As all the angiotensin converting enzyme inhibitors currently listed in the British National Formulary are excreted renally, it is easy to understand why stopping treatment in the presence of renal failure is not necessarily followed by a rapid improvement in renal function.

We believe that in any patient with clinically evident non-renal vascular disease angiotensin converting enzyme inhibitors should not be used unless atheromatous renal artery disease has been excluded. As this can be done adequately only by angiography it seems simpler to avoid using these inhibitors in such patients unless a conventional stepped care regimen proves inadequate. The increasing advocacy of angiotensin converting enzyme inhibitors as the test treatment for hypertension ignores not only the financial cost of these drugs $^{+}$but the dangers in the many hypertensive patients who have generalised vascular disease.

Finally, as it is clear that atheromatous renal artery disease is an incidental finding in a considerable proportion of normotensive patients it can only be concluded that it is also an incidental finding in many hypertensive patients with vascular disease. Despite this using angioplasty to treat hypertensive patients with renal artery disease is becoming increasingly widespread without controlled trials showing benefit. Such trials are urgently needed.

JOHN MAIN MICHAEL WARD

Royal Victoria Infirmary,

Newcastle upon Tyne NE1 4LP

HENRY LOOSE ROBERT WILKINSON

Freeman Hospital,

Newcastle upon Tyne NE7 7DN

I Choudhri AH, Cleland JGF, Rowlands PC, Tran TL, McCarty $M$, Al-Kutoubi MAO. Unsuspected renal artery stenosis
in peripheral vascular disease. $B M \mathcal{F} 1990 ; 301: 1197-8$. (24 November.

2 Bonomo L, de Pascale A, Dell'Orso E, et al. Evaluation of the renal arteries with digital angiography in patients with the renal arteries with digital angiography
peripheral arteriopathy. Rays 1988;13:49-52.

3 Joint Formulary Committee. British National Formulary. London: British Medical Association, Royal Pharmaceutical London: British Medical Association, Royal Pharma
Society of Great Britain, 1990:76. (No 20, September.)

4 Swales JD. First line treatment in hypertension. BMF 1990;301: 1172-3. (24 November.)

SIR,-The findings of $\mathrm{Dr} \mathrm{A} \mathrm{H}$ Choudhri and colleagues' are supported by my and my colleagues' results. ${ }^{2}$

During 1988 and 1989 we examined 72 patients presenting with atherosclerotic aortoiliac disease by aortography and renal arteriography. ${ }^{2}$ Thirty five patients were found to have anatomical renal artery stenosis. All patients were also examined by quantitative renography with technetium $-99 \mathrm{~m}$ and pentetic acid to measure renal perfusion. We found a poor correlation between the results of arteriography and isotope renography: renography confirmed renal artery stenosis in only eight patients. When the results of arteriography were taken as the definitive standard isotope renography seemed to have a high specificity $(84 \%)$ but a low sensitivity $(23 \%)$, probably because most anatomical stenoses detected by arteriography do not lead to a functional disturbance.

Though I agree that the prevalence of anatomical renovascular disease among patients with atherosclerotic peripheral vascular disease is high, there is an important difference between anatomical and functional renal artery stenosis. Furthermore, the relation between functional stenosis and renal pathology (renal hypertension and impaired renal function) is far from clear and can confidently be defined only retrospectively after correction of the renal artery abnormality. Nevertheless, anatomical renal artery stenosis (without functional or pathological sequelae) can progress to total occlusion and infarction of functioning renal tissue. This can occur without causing renal hypertension or a deterioration of overall renal function. Dr Choudhri and colleagues advise caution when prescribing angiotensin converting enzyme inhibitors to patients with peripheral vascular disease. I would go further and advise that these drugs be avoided altogether.

Sir Charles Gairdner Hospital,

H GAJRAJ

Perth,

Western Australia
1 Choudhri AH, Cleland JGF, Rowlands PC, Tran TL, McCarty $\mathrm{M}, \mathrm{Al}-\mathrm{Kutoubi}$ MAO. Unsuspected renal artery stenosis in peripheral vascular disease. $B M \mathcal{J}$ 1990;301:1197-8. (1 December.)

2 Gairaj H, Judge J, Low V, House AK. Technetium-99m renography screening of renal artery stenosis in hypertensive patients with peripheral vascular disease. Br f S Surg (in press).

SIR,-Dr A H Choudhri and colleagues conclude that angiotensin converting enzyme inhibitors should be used with caution in patients with peripheral vascular disease because of the high prevalence of renal artery stenosis.' We suggest that similar caution is necessary in hypertensive patients with non-insulin dependent diabetes. Angiotensin converting enzyme inhibitors are often recommended for diabetic patients because they do not exacerbate hyperglycaemia. ${ }^{2}$

Ritchie et al found a $20 \%$ prevalence of renal artery stenosis in hypertensive patients with non-insulin dependent diabetes and concluded that it was a consequence rather than a cause of the hypertension. ${ }^{3}$ In a study comparing the effects of captopril and placebo on blood pressure we found that two of 16 patients with non-insulin dependent diabetes randomised to captopril had an unexpected fall in glomerular filtration rate as measured by clearance of EDTA labelled with chromium-51..$^{+}$In the first case a 60 year old man with a 15 year history of hypertension had a blood pressure of $186 / 104 \mathrm{~mm} \mathrm{Hg}$, serum creatinine concentration $78 \mu \mathrm{mol} / 1$, and glomerular filtration rate $114 \mathrm{ml} / \mathrm{min} / 1.73 \mathrm{~m}^{2}$ at randomisation. After two months on captopril $25 \mathrm{mg}$ twice daily he stopped the drug because of postural dizziness and "muzzy heads." At the three month visit his blood pressure was $189 / 109 \mathrm{~mm} \mathrm{Hg}$, serum creatinine concentration $81 \mu \mathrm{mol} / \mathrm{l}$, and glomerular filtration rate $73 \mathrm{ml} / \mathrm{min} / 1 \cdot 73 \mathrm{~m}^{2}$. Prazosin was started and six months later his blood pressure was $71 / 102 \mathrm{~mm} \mathrm{Hg}$, creatinine concentration $92 \mu \mathrm{mol} / \mathrm{l}$, and glomerular filtration rate $107 \mathrm{ml}$ $\min / 1.73 \mathrm{~m}^{2}$. In the second case a 66 year old woman with a five year history of hypertension had a blood pressure of $160 / 105 \mathrm{~mm} \mathrm{Hg}$, serum creatinine concentration $65 \mu \mathrm{mol} / \mathrm{l}$, and glomerular filtration rate $75 \mathrm{ml} / \mathrm{min} / 1.73 \mathrm{~m}^{2}$ at randomisation. After three months on captopril $25 \mathrm{mg}$ twice daily her blood pressure was $133 / 82 \mathrm{~mm} \mathrm{Hg}$, serum creatinine concentration $88 \mu \mathrm{mol} / \mathrm{l}$, and glomerular filtration rate $48 \mathrm{ml} / \mathrm{min} / 1.73 \mathrm{~m}^{2}$. Captopril was discontinued. After six months her blood pressure was $158 / 94 \mathrm{~mm} \mathrm{Hg}$, creatinine concentration $111 \mu \mathrm{mol} / 1$, and glomerular filtration rate $39 \mathrm{ml} /$ $\min / 1.73 \mathrm{~m}^{2}$. Glomerular filtration rate remained low at $48 \mathrm{ml} / \mathrm{min} / 1.73 \mathrm{~m}^{2}$

Intravenous urography, renal ultrasonography, and digital subtraction angiography all gave normal results in both patients. The decline in renal function after they started to take an angiotensin converting enzyme inhibitor would not have been detected in ordinary clinical practice as renal function is routinely assessed by measuring serum creatinine concentration. Serum creatinine concentration is recognised to be an insensitive reflection of renal function, ${ }^{5}$ and measuring creatinine clearance is unreliable and, in this age group, impractical owing to the difficulty of collecting a 24 hour urine sample as an outpatient. ${ }^{6}$ The cost implications of using isotopes to assess glomerular filtration rate are great but may have to be considered for patients with diabetes and hypertension who require lifelong treatment with angiotensin converting enzyme inhibitors.

DAVID KERR ROBERT TATTERSALL

Queen's Medical Centre,

Nottingham NG7 2UH

1 Choudhri AH, Cleland JGF, Rowlands PC, Tran TL, McCarty $M$, Al-Kutoubi MAO, Unsuspected renal artery stenosis in peripheral vascular disease. $B M 7$ 1990:301:1197-8. (24 November.

2 Corcoran JS, Perkins JE, Hoffbrand BI, Yudkin JS. Treating hypertension in non-insulin dependent diabetes: a comparison 
atenolol, nifedipine and captopril combined with bendrofluazide. Diabetic Med 1987;4:164-8.

3 Ritchie CM, McGrath E, Hadden DR, Weaver JA, Kennedy L, Atkinson $A B$. Renal artery stenosis in hypertensive diabetic Atkinson AB. Renal artery stenosis.

4 Chantler G, Garrett ES, Parsons V, Veall N. Glomerular filtration rate measurement in man by the single injection method using rate measurement in man by the sing
${ }^{5}$ Cr-EDTA. Clin Sci 1969;37:169-80.

5 Levy AS, Perrone RD, Madias NE. Serum creatinine and renal function. Annual Review of Medicine 1988;39:465-90.

6 Gabriel R. Time to scrap creatinine clearance? BMJ 1986;293: 1119-20.

\section{First line treatment in hypertension}

SIR, - Professor J D Swales's editorial' comes at a propitious time, a time when the government is endorsing health promotion clinics that include managing hypertension.' We believe, however that many issues in the contemporary management of hypertension deserve inclusion in the recommendations for first line treatment.

Firstly, non-pharmacological management options, including weight reduction, restriction of dietary salt intake, and alcohol limitation should, in our view, be the real first line treatment. This approach needs more emphasis before discussing the issue of which drug to use. All drug treatments, even those two groups of drugs favoured by Professor Swales, have been associated with well documented subjective as well as metabolic side effects. ${ }^{2}$

Secondly, the failure of trials of thiazide diuretics and $\beta$ blockers to find an effect on coronary heart disease indicates the possible importance of other risk factors and the complex interactions with antihypertensive treatment. These observations are made against a background of an alarmingly high incidence of cardiovascular disease in industrialised countries $(>150000$ deaths/year in the United Kingdom ${ }^{3}$ and $>750000 /$ year in the United States ${ }^{+}$. With recent data showing that over half the hypertensive population have a more atherogenic lipid profile than do normotensive subjects $^{56}$ influences on lipid and lipoprotein concentrations may be critical in determining atherosclerotic disease related to hypertension. The impact of lipid lowering on coronary heart disease is well documented. Consensus recommendations from both the United Kingdom ${ }^{7}$ and the United States ${ }^{8}$ advise caution in using drugs that adversely affect lipid and lipoprotein concentrations, including thiazides and $\beta$ blockers.

Furthermore, thiazides and $\beta$ blockers would be inappropriate in diabetic subjects, who have a high prevalence of hypertension and large vessel complications. There is good documentation that these drugs may worsen glucose tolerance and promote an atherogenic lipid profile in both diabetic and non-diabetic patients. ${ }^{910}$ The newer drugs, by comparison, have a neutral or a beneficial effect on lipid concentrations. ${ }^{10}$ There may, however, be a good case for using diuretics at substantially lower doses than officially recommended as effective blood pressure reduction has been observed with reduced adverse effects on other risk factors."

Thirdly, an assessment of the costs and benefits, including risk factors for coronary heart disease should be favoured, ${ }^{3}$ and not just a simple comparison of the cost effectiveness of the "older" and "newer" antihypertensive drugs. Of importance in cost benefit analyses are not only the effects on glucose homoeostasis and a potential atherogenic lipid profile but the reduced hypotensive effect of $\beta$ blockers in people who smoke ${ }^{2}$ and black people with hypertension"'; their unsuitability in the elderly people; and their wider side effects.

We suggest that antihypertensive treatment should be personalised and take into account other risk factors. ${ }^{131+}$ The benefits of this approach will accrue favourably in population mortality statistics without the need to conduct expensive trials with more expensive drugs. We are falling behind our transatlantic colleagues in not accepting the therapeutic advances of the past decade. ${ }^{121+} \mathrm{We}$ are fortunate to enter the 1990s with a wide range of drugs for the treatment of hypertension. This should allow the choice of first line drug to be widened.

MICHAEL D FEHER ARIEL LANT

Charing Cross and Westminster Hospital School, London SW1 $2 \mathrm{AP}$

Swales JD. First line treatment in hypertension. BMF 1990; 301:1172-3. (24 November.)

2 Medical Research Council Working Party. MRC trial of treatment of mild hypertension: principal results. $B M \mathcal{F}$ 1985;291:97-104

3 Office of Health Economics. Coronary heart disease. The need for action. London: HMSO, 1990.

Leaf A, Ryan TJ. Prevention of coronary artery disease. $N$ Engl f Med 1990;330:1416-9.

5 Castelli WP, Anderson $K$. A population at risk. Prevalence of high cholesterol levels in hypertensive patients in the Framingham study. Am f Med 1986;80 (supply 2A):23-32. 6 Curzio JL, Kennedy FS, Elliot H, et al. Hypercholesterolaem in treated hypertensives. $\mathcal{F}$ Hypertens 1989;7 (suppl 6): in treas.

7 Shepherd J, Betteridge DJ, Durrington P, et al. Strategies for reducing coronary heart disease and desirable limits for blood lipid concentrations: guidlines of the British Hyperlipidaemia Association. BMf 1987;295:1245-6.

8 Consensus conference. Lowering blood cholesterol to prevent heart disease. JAMA 1985;253:2080-6

9 Feher MD, Henderson AD, Wadsworth J, et al. Alpha-blocker therapy; a possible advance in the treatment of diabetic hypertension - results of a cross-over study of doxazosin and atenolol monotherapy in hypertensive non-insulin dependent diabetic subjects. F Hum Hypertens 1990;4:571-7.

10 Weidmann P, Ferrier C, Saxenhofer H, et al. Serum Lipoproteins during treatment with antihypertensive drugs. Drugs 1988;35 (suppl 6): 118-34

11 Carlsen JE, Kober L, Torp-Pedersen C, Johansen P. Relation between dose of bendrofluazide, antihypertensive effect and between dose of bendrofluazide, antihypertensive effect and
adverse biochemical effects. BMF 1990;300:975-8. (14 April.) 12 Weinberger MH. Racial differences in antihypertensive therapy; einberger MH. Racial differences in antihypertensive therapy;
evidence and implications. Cardiovascular Drugs and Therapy evidence and in

13 Kannel WB. Hypertension: relationship with other risk factors. Drugs 1986;31(suppl 1):1-11.

4 Moser $M$. Antihypertensive medications; relative effectiveness and adverse reactions. F Hypertens 1990;8 (suppl 2):S9-16.

SIR,-Professor J D Swales's recent editorial, though pragmatic, ignores several key issues.

It is true that there are no data on long term morbidity and mortality with the newer drugs ( $\alpha$ blockers, angiotensin converting enzyme inhibitors, and calcium antagonists), and even if a trial were to start tomorrow the results would not be available for 10 years. Unfortunately, no such data may ever be forthcoming owing to the prohibitive costs. But does this mean that we must persevere slavishly with diuretics and $\beta$ blockers, which have repeatedly been shown to be disappointing in terms of reducing coronary heart disease?

Three to four myocardial infarctions attributable to elevated blood pressure occur for each stroke; consequently preventing coronary heart disease must be the primary aim of treatment. We therefore cannot gloss over the shortfall in the effect on coronary heart disease and ignore the potential benefits of the newer drugs.

We do have data suggesting that the newer drugs may be better than diuretics and $\beta$ blockers in terms of preventing coronary heart disease. The treatment of mild hypertension study showed lasting, significant adverse effects on lipid profiles with a low dose diuretic (chlorthalidone) and a lipid friendly $\beta$ blocker (acebutolol), whereas the newer drugs were shown to be lipid neutral or, in the case of the $\alpha$ blocker (doxazosin), to improve lipid profiles. ${ }^{2}$ The newer drugs do not have adverse effects on glucose intolerance and insulin resistance in contrast with diuretics and $\beta$ blockers; nor do they produce the hyperuricaemia and hypokalaemia induced by diuretics. All these variables have an adverse impact, directly or indirectly, on coronary heart disease events. Is it not more rational to be swayed by the advantages of the newer drugs than by subgroup analyses of the Medical Research Council's trial?

We agree that diuretics and $\beta$ blockers should be reserved for patients with uncomplicated hypertension. Unfortunately, over $85 \%$ of hypertensive patients have adverse lipid profiles, ${ }^{3}$ which merit intervention (as recommended by the European Atherosclerosis Society and the British Hyperlipidaemia Association); up to half have left ventricular hypertrophy ${ }^{4}$; and over $10 \%$ have glucose intolerance ( $P$ McKeigue, unpublished observations). The use of diuretics and $\beta$ blockers in the face of any of these three complications is at best suboptimal and probably contraindicated. ${ }^{5-8}$

NEIL POULTER SIMON THOM PETER SEVER

St Mary's Hospital

London W2 1 NY

1 Swales JD. First line treatment in hypertension. BMf 1990;301: 1172-3. (24 November.)

2 Mascioli S, Svendsen K, Grimm R, et al. One year lipid changes by class of anti-hypertensive drug in the treatment of mild hypertension study (TOMHS). In: Proceedings of second intermational conference on preventive cardiology. Dallas: American Heart Association, 1989:86.

3 Langdon CG. Doxazosin: a study in a cohort of patients with hypertension in general practice-an interim report. Am Heart $\mathcal{F}$ (in press).

4 Hammond IW, Devereux RB, Alderman MH, et al. The prevalence and correlates of echocardiographic left ventricular hypertrophy among employed patients with uncomplicated hypertension. I Am Coll Cardiol 1986; 7:639-50.

5 Weidman P, Vehlinger DE, Gerber A. Antihypertensive treatment and serum lipids. $\mathcal{F}$ Hypertens 1985;3:297-306.

6 Drayer JI, Gardin JM, Weber MA, Aronow WS. Changes in ventricular septal thickness during diuretic therapy. Clin Pharmacol Ther 1982;32:283-8.

7 Murphy MH, Kohner E, Lewis PJ, Schumer B, Dollery CT. Glucose intolerance in hypertensive patients treated with Glucose intolerance in hypertensive patients treated with
diuretics: a fourteen year follow-up. Lancet 1982;ii: 1293-5.

8 British Heart Foundation. Fact file on treatment of hypertension. London: British Heart Foundation, 1990.

\section{General practice experience of patient recall}

SIR,-Half of the first year of the new general practitioner contract has now passed. We present an interim analysis of some of the extra work that we have been doing to meet our terms of servicenamely, recalls for elderly patients and those aged 16-74 not seen for three years.

To spread the work evenly through the year we recalled our patients on a monthly basis by patient's month of birth. We can therefore review those patients born in the months April to September. We had 6236 patients registered on 1 April 1990: about a third were eligible for the deprivation allowance. We have an annual turnover of $20 \%$. Elderly patients were invited to make an appointment and those aged 16-74 not seen for three years were offered a specific appointment in the afternoon, with an option to rearrange their appointment if it was unsuitable. The table shows the results; only five letters were returned "not known at this address." We have also taken over the list of a neighbouring practice. Recalling 26 of these patients to a clinic for their registration checks produced an attendance of three (with no cancellations).

Attendance of patients recalled for routine check up

\begin{tabular}{lcccc}
\hline Age & $\begin{array}{c}\text { No of } \\
\text { patients } \\
\text { on list }\end{array}$ & $\begin{array}{c}\text { No } \\
\text { recalled }\end{array}$ & $\begin{array}{c}\text { No who } \\
\text { declined } \\
\text { to attend }\end{array}$ & $\begin{array}{c}\text { No (\%) } \\
\text { who } \\
\text { attended }\end{array}$ \\
\hline$\geqslant 75$ & 197 & 197 & 12 & $75(38)$ \\
$\begin{array}{l}16-74: \\
\text { Men }\end{array}$ & 1049 & 205 & 8 & $16(8)$ \\
Women & 961 & 154 & 5 & $30(19)$ \\
\hline
\end{tabular}

Those general practitioners who have not begun recalling patients can fairly confidently book two elderly patients or five patients aged 16-74 for every appointment. The average general practitioner with a list of 2000 in a similar inner city practice would need to see about 80 patients 